\title{
Effect of School and Head Management Teacher Academic Qualifications on Quality of Basic School Education in Kisam Tinggi District
}

\author{
A. Zarkasi ${ }^{1 *}$, Happy Fitria ${ }^{2}$, Yenny Puspita ${ }^{2}$
}

\author{
${ }^{I}$ SDN 08 Kisam Tinggi \\ ${ }^{2}$ Universitas PGRI Palembang \\ *Corresponding author. Email: a.zarkasimutia@gmail.com
}

\begin{abstract}
This study aims to know the effect of principal management and teacher academic qualifications together on improving the quality of school education. We used quantitative approach with principal and teachers in Kisam Tinggi District as sample. In this study, data collection used three techniques, namely questionnaires, documents, and unstructured interviews. There are positive and significant effect of principal management and teacher academic qualifications together on improving the quality of school education. The suggestions put forward by the author are as follows. The findings of this study indicate that principal management and teacher academic qualifications have an influence.
\end{abstract}

Keywords: Management, Academic Qualifications, Quality of Education

\section{INTRODUCTION}

An organization is formed from several interrelated components and forms a complete system and cannot be separated from one component to another. It is an educational institution that is an organization formed from components including students, educators, educational staff, school leaders, the community, and school committees. Each of these components has a duty and function, has responsibilities that it carries. Educators have the function of providing education and teaching to students. The educational staff functions to organize all technical activities of documentaries learning, which is no less important is the manager in educational institutions' administration educational institutions' administration.

The center of all teacher activities and school administrative personnel is driven by the educational institution leader, namely the Head of the School. The principal functions as a manager of the entire course of teacher activities, in addition to this task has an important manager role in dynamizing learning activities inside and outside the classroom. Based on Permendiknas number 13 of 2007, several competencies must be possessed by prospective school principals, namely personality competence, managerial competence, entrepreneurial competence, supervisory competence, and social competence [1].

The three sub-managerial skills of the principal are in accordance [2] opinion, that "The principal as a manager really needs three kinds of managerial skills, namely concept skills, technical skills, and human relations skills." Furthermore, the importance of principal managerial skills, namely: "The principal is a manager who occupies three levels of manager. The principal is as a top-level manager within the school, as a middle-level manager in the Education Office, and as a lower-level manager in the Ministry of Education" [3].

The most important thing from this research is that the principal as a manager is required to have qualified managerial skills. From the aspect of responsibility, it can be seen that the principal is clearly taller, and the problem is complex, compared to other education personnel at the school level. Therefore, the progression of an educational institution is determined by the extent to which the principal in one unit and one level of education can move the available components with the principal's managerial skills. The more he is able to dynamize teachers, the greater his chances of becoming a reliable leader who can manage educational institutions professionally.

The Indonesian government has shown its seriousness in increasing the capacity of teachers by 
paying attention to welfare through measures including functional allowances and subsidies for functional allowances, increasing professionalism by holding teacher certification, and having a high enough position to strengthen their role in schools. But on the contrary, in the field, there are many cases that reflect where there are still many teachers who educate not according to their competence, level of education, etc. In addition, there are various teacher behaviors, such as skipping work for various reasons, tardiness, being on time and discipline in carrying out work, looking attractive, implementing less attractive learning, and so on.

Work culture could be a reasoning based on a see of life as values that become characteristics, propensities, and driving powers, culture within the life of a community gather or organization, at that point reflected in the state of mind into behavior, convictions, thoughts, suppositions,

and activities show as work or work [4]. All of the descriptions above indicate that teacher performance in teaching is influenced by school principals' management ability, which will have an impact on the quality of education in schools. In addition to school principals' managerial abilities, in the world of education, teachers have an important role in the quality of education. Improving the quality of teachers is the main because the competence of teachers who have not met the standards is still large. Such as a lack of knowledge and skills of teachers in managing learning activities, teacher mastery of learning materials is still lacking, teacher personality is still unstable, and the ability of educators as part of society is still low.

The teaching profession has been recognized for its existence, as well as the fulfillment of professional demands as a teacher must be raised in order to create teachers who are qualified, have competence, have a deep understanding of what they do, are competent in managing effective and efficient learning and have a strong character or personality. Conversely, unprofessional teachers have a negative influence on the achievement of students.

As professional educators, teachers must meet a number of requirements, both academic qualifications and competencies. Teacher education also generally does not meet the minimum qualification standards. It is hoped that academic qualifications can reflect the ability of educators in the education unit they serve according to national education standards.

"The low quality of education in Indonesia is caused by low qualifications and competence of teachers who tend to be unqualified, underqualified, and mismatched".
The low qualifications and competence of teachers and the mismatch of educational backgrounds certainly have an impact on the learning that will be given to students. In line with the results of research, that the teacher's inadequacy in teaching is influenced by several factors such as; the mismatch of the educational background with the subject that is being handled, the teacher's busyness, and the inability to design and implement and evaluate learning [5].

Teachers play a vital role in attempts to increase the standard of formal education. Teachers, as learning agents, must be capable of carrying out the learning process as effectively as possible within the context of educational development. The evaluation of how a product follows those requirements, guidelines, or references is fundamental to quality education. In the educational sector. The method of assessing educational quality is fluid and can be studied from a number of perspectives. The agreement on the concept of quality is returned to the formulation of references or existing references such as education policies, teaching and learning processes, curricula, facilities and infrastructure, learning facilities, and education personnel in accordance with the agreement of the parties concerned [6].

In the Big Indonesian Dictionary, "Quality" means rust. Good or bad something, quality, level or degree. In general, 'quality' can be defined as «the characteristics of a product or service that are determined by the customer and obtained through process measurement and continuous improvement. Quality is a comprehensive description and characteristics of goods or services that show their ability to satisfy the expected needs in the context of education. The notion of quality includes educational inputs, processes, and outputs [6].

The school determines the quality of education as a teaching institution, but it is adjusted to the community's views and expectations that develop along with the times. A school that is successful in improving the quality of its education is determined by factors including Formulation of the Vision, Mission and Purpose of School SelfEvaluation Schools The role of school principals to improve teacher quality [7]. Management is a typical process that consists of planning, organizing, mobilizing, and controlling actions carried out to achieve predetermined goals through human resources and other sources. Management is the ability or skills of a person to obtain something to achieve goals through other people's activities [8].

Principles in management are flexible in the sense that they need to be considered according to special conditions and changing situations. According to Fayol, a management theory originator from France, the general 
principles of management consist of the division of labor, authority, and responsibility, discipline, unity of command, unity of direction, prioritizing organizational interests above their own interests, employee payroll, concentration, Hierarchy, Orderliness, Justice and honesty, Stability of employee conditions, Initiative, a spirit of unity, spirit of corps. The term principal comes from the two words principal and school. Head can be interpreted as chairman or leader. Both of them face or head a group and both of them have responsibilities.

Previous study about management competence to improvee quality of school has conducted and the results showed that the principal's management competence in improving the quality of education in Lais Regency is well [9]. This study and the research conducted have in common. They both examine the management of school principals as a variable and the quality of education. While the difference is only in the variable limitation where in this study examining variable academic qualifications. Even though it has differences, this study's results are research data on principal managerial variables and the quality of education can be used as a reference and comparison for the research data conducted.

There have been the previous study on the benefits of school principals in managing schools to improve primary schools' quality of education. This study used a qualitative method with a phenomenological naturalistic type and it was found that principals who have good school management skills can improve the quality of education [10].

\section{METHODS}

Data of this study can present the quality of teacher performance, the management ability of school principals and the level of academic qualifications of teachers, elementary schools in Kisam Tinggi District. This research was conducted from October to November 2020.

This research is a type of quantitative research by planning the research design and structure in order to get the answers needed for research, this type of research is deductive in finding answers to problem formulations using expert concepts and theories so that they are able to generate a hypothesis [11]. Calculating the range of data, namely the largest data minus the smallest data. Class length, namely the data range divided by the number of classes. Furthermore, the existing data were analyzed using the help of the SPSS version 16.0 program. Testing Requirements Analysis The data normality test was performed using the Kolmogorov Smirnov Test SPSS analysis.
The provisions in the Kolmogorov Smirnov Test if the significant count $>0.05$ means that the data is normally distributed, on the contrary, if the significance level is $<0.05$ then it is not normally distributed. Tolerance is a statistically justified error rate, whereas VIF is the squared standard deviation inflation factor. If the number at tolerance shows $>0.1$ and VIF shows $<10$ then multicollinearity does not occur. Conversely, if the numbers in the tolerance column show $<0.1$ and VIF indicates $>10$, multicollinearity occurs [11]. Data analysis using simple regression was used to test the truth of hypotheses 1 and 2 , namely the effect of principal management on the quality of education in schools and the effect of teacher academic qualification on the quality of education in schools.

\section{RESULTS AND DISCUSSION}

Before the analysis is carried out, the conditions must first must be normally distributed, the variables must be linear, and multicollinearity does not occur between independent variables. The normality test was carried out with the help of SPSS 20.0 for windows using the Kolmogorov-Smirnov method.

The linearity test between the Principal Management variable and the Education Quality variable obtained $\mathrm{F}$ count of 1.358 at the $5 \%$ significant level. F count is smaller than $\mathrm{F}$ table, so it can be concluded that the principal management variable and the education quality variable have a linear relationship. While the linearity test between the variable teacher academic qualification and the education quality variable obtained $\mathrm{F}$ count of 0.657 at a significant level of $5 \%$. The multicollinearity test is to determine the symptoms of multicollinearity between independent and dependent variables.

Based on the analysis, it is known that the coefficient of determination is 0.194 . This value is then converted into percentage form to $19.7 \%$, which means that the principal management is able to explain $19.4 \%$ of changes in the quality of education, while other factors influence $80.6 \%$ other factors influence $80.6 \%$. The significant test aims to determine the significance of principal management's influence on the quality of education. Based on the results of the $t$ test, the $t$ value was 5.77 .

The second hypothesis in this study is, "There is a positive and significant influence between academic qualifications on the quality of education. The equation shows that the value of the X2 coefficient is 1.648 which means that if the academic qualification value is 1 unit, the value of education quality will increase by 1.648 
units. The table above is 0.327 . Based on the analysis in the table above, it is known that the coefficient of determination is 0.101 . This value is then converted into percentage to $10.1 \%$, which means that teachers' academic qualifications can explain $10.1 \%$ changes in the quality of education and the rest is influenced by other factors. Significant test aims to determine the significance of the effect of academic qualifications on the quality of education Based on the results of the $t$ test, the $\mathrm{t}$ value is 3,942 .

The third hypothesis in this study is, "There is a positive and significant influence between the management of the principal and teachers' academic qualifications together on the quality of education in Kisam Tinggi District".

The total of the Effective Contribution is $22.7 \%$, which means that together the principal management variables and academic qualifications provide an Effective Contribution of $22.7 \%$ to the quality of manual typing education, while $77.3 \%$ is given by other variables not discussed in this research.

The results of the calculation using a simple regression analysis that the correlation coefficient is positive. So, there is a positive effect of the principal management variable on the quality of education, where each additional value of 1 in the school head management variable will give a change in the value of the variable quality of education. While the coefficient of determination that the result is compared with the t-table. It can be concluded that there is a positive and significant effect of principal management on the quality of primary school education in Kisam Tinggi District effective contribution of principal management to the quality of education. This study also indicates that the principal is the most important person in a school because the principal is the key to the development and improvement of a school.

This proves that the principal's managerial competence has a significant effect on the quality of education at SMPN 3 Sungguminasa. Based on the results of calculations reinforced by theory and research results, the quality of education is influenced by the management of the principal. Therefore, the principal is required to have good managerial abilities so that the quality of education is good.

The results showed that principals' management competence in improving the quality of education in Lais District increased. This study's results are in line with the research of Kurniawati et al [10] concerning the Role of Principal Leadership in Improving the Quality of Education through School-Based Management. The principal plays a role as a leader and manager and other roles in efforts to improve the quality of education. It can be seen from school principals, teachers, and employees' performance in collaborating and establishing communication in carrying out every activity that is their duty and responsibility for the achievement of quality education.

\section{CONCLUSION}

Based on the result, there are positive and significant effect of principal management and academic qualifications on the quality of primary school education in Kisam Tinggi District. It is shown that the higher the level of management ability of the principal and academic qualifications, the higher the quality of education he achieves. Good management of school principals affects the quality of education in schools. Therefore, the principal is required to have good management skills so that the quality of education in the school he leads is good. With the higher the principal's level of management ability, the higher the quality of education. Schools that have teachers with good academic qualifications produce good quality education. This is indicated by the higher academic qualifications, the higher the quality of education.

\section{REFERENCES}

[1] Mulyasa, E. (2014). Menjadi Kepala Selolah Profesional dalam Konteks Menyukseskan MBS dan KBK. Bandung: Remaja Rosdakarya

[2] Wahjosumidjo. (2013). Kepemimpinan Kepala Sekolah"Tinjauan teoritik dan Permasalahannya. Jakarta: Penerbit PT Raja Grafindo Persada.

[ 3 ] Mulyasa. (2019). Menjadi Kepala Sekolah Profesional. Bandung: remaja Rosdakarya

[4] Triguno. SG. (2016). Budaya Kerja Organisasi Pemerintah. Jakarta: LAN-RI.

[5] Effendi, M. (2018). Analisis Kualifikasi dan Kompetensi Profesi Guru serta Upaya Pengembangannya dalam Menyikapi UU GuruDosen (studi di Pendidikan Dasar dan Menengah Kota Malang).

[6] Arcaro, S. J. (2015). Pendidikan Berbasis Mutu, Prinsip-prinsip Perumusan dan Tata Langkah Penerapan. Jakarta: Rineka Cipta.

[ 7 ] Sagala, S. (2010). Supervisi Pembelajaran dalam Profesi Pendidikan. Bandung: Alfabeta. 
[ 8 ] Poerwadarminta, WJS. (2012). Kamus Umum Bahasa Indonesia, Jakarta: Rineka Cipta

[9] Komalasari, K., Arafat, Y., \& Mulyadi, M. (2020). Kompetensi Manajemen Kepala Sekolah dalam Meningkatkan Mutu Pendidikan. Jurnal Pekerjaan Sosial dan Pendidikan Sains, 1 (2), 181-193.

[ 10 ] Kurniawati, E., Arafat, Y., \& Puspita, Y. (2020). Peran Kepemimpinan Kepala Sekolah dalam Meningkatkan Mutu Pendidikan melalui Manajemen Berbasis Sekolah. Journal of Education Research, 1(2), 134-137. https://doi.org/10.37985/joe.v1i2.12

[11] Hoy, W. K., \& Adams, C. M. (2015). Quantitative research in education: A primer. Sage Publications. 